\title{
Karol Flisek
}

Uniwersytet Jagielloński

karol.flisek@student.uj.edu.pl

\section{Zwrot wywłaszczonej nieruchomości}

\author{
Return of Expropriated Estate
}

\begin{abstract}
STRESZCZENIE
Artykuł dotyczy instytucji zwrotu wywłaszczonej nieruchomości. Pierwsza część jest poświęcona nakreśleniu wywłaszczenia jako władczej konstrukcji prawa publicznego w świetle elementarnych zasad konstytucyjnych oraz całego polskiego porządku prawnego. Wywłaszczenie opisano, wymieniając i omawiając poszczególne jego przesłanki, zarówno pozytywne, jak i negatywne. We właściwej części tekstu autor skupia się na ustawowej instytucji zwrotu wywłaszczonej nieruchomości, opisanej w art. 136 i n. ustawy z dnia 21 sierpnia 1997 r. o gospodarce nieruchomościami, wokół której - w świetle serii wywłaszczeń dokonanych w trakcie rozwoju powojennego systemu politycznego Polski - narosło sporo wątpliwości prawnych. W opracowaniu jest rozważana każda istotna przesłanka zwrotu, między innymi kwestia uznania nieruchomości za zbędną na cele wywłaszczenia (w doktrynie wydaje się ona być niedyskutowana należycie), z omówieniem przy tym głównych poglądów doktryny i orzecznictwa. Autor wysuwa kilka istotnych postulatów de lege ferenda w celu jaśniejszego ukształtowania wyżej wymienionej konstrukcji.
\end{abstract}

Słowa kluczowe: zwrot; wywłaszczenie; nieruchomość; zbędność; gospodarka nieruchomościami

\section{WSTĘP}

Instytucję zwrotu wywłaszczonej nieruchomości reguluje ustawa z dnia 21 sierpnia 1997 r. o gospodarce nieruchomościami ${ }^{1}$ w art. 137 i n. Konstrukcja wywłaszczenia, jako jeden z najdobitniejszych przejawów władztwa, które ma administracja publiczna, opisana jest w art. 112 i n. wyżej wymienionej ustawy. W związku z doniosłością prawną i ekonomiczną zwrotu wywłaszczonej nieru-

1 Ustawa z dnia 21 sierpnia 1997 r. o gospodarce nieruchomościami (t.j. Dz.U. z 2015 r., nr 1774), dalej jako: u.g.n. 
chomości szczególnie ważna jest w tym przypadku wykładnia przepisów dotyczących tej konstrukcji, która powinna uwzględniać wyjątkowy charakter instytucji poprzez ochronę praw podmiotu wywłaszczonego, a jednocześnie zapewniać pewność prawa i skuteczne wykonywanie celów publicznych objętych decyzją o wywłaszczeniu. Jako problem jawi się tutaj częste odwoływanie się literatury przy interpretowaniu tekstu ustawy do sposobu wykładania przepisów prawa cywilnego, co - biorąc pod uwagę publicznoprawny charakter przepisów dotyczących zwrotu wywłaszczonej nieruchomości - należy uznać za niewłaściwe. W celu pełnego omówienia zagadnienia zwrotu wywłaszczonej nieruchomości konieczna wydaje się uprzednia analiza przepisów statuujących samą instytucję wywłaszczenia, zarówno rangi konstytucyjnej, jak i ustawowej. W przeciwnym wypadku wywód stanowiłby niepełny obraz instytucji będącej przedmiotem artykułu.

\section{INSTYTUCJA WYWŁASZCZENIA W ŚWIETLE KONSTYTUCJI RZECZYPOSPOLITEJ POLSKIEJ ORAZ USTAWY O GOSPODARCE NIERUCHOMOŚCIAMI}

Przede wszystkim należy stwierdzić, że zasadniczo ustrój Rzeczypospolitej Polskiej chroni prawo własności. Wynika to wprost z Konstytucji $\mathrm{RP}^{2} \mathrm{z}$ art. 21 ust. 1. Część autorów twierdzi, że „zagwarantowanie prawa własności nie oznacza bynajmniej, że jest ona nienaruszalna"’3. To określenie wydaje się jednak zbyt radykalne. Należy bowiem przyjąć, że własność według Konstytucji RP jest w istocie swej nienaruszalna, ponieważ zasadniczo każde jej naruszenie spotyka się z negatywną dla naruszającego reakcją przewidzianą przez prawo. Bardziej odpowiednie wydaje się stwierdzenie, że zasada ochrony własności nie jest zasadą absolutną, gdyż już sam art. 21 ust. 2 przewiduje wyjątek w postaci wywłaszczenia. Możliwość wywłaszczenia ogranicza następnie art. 64 ust. 3 Konstytucji RP, który stanowi wyłączność ustawy jako podstawy wywłaszczenia.

Wywłaszczenie w rozumieniu art. 21 Konstytucji RP należy interpretować szeroko. Konstytucyjne pojęcie wywłaszczenia nie pokrywa się w związku z tym z konstrukcją prawną z art. 112 u.g.n. W świetle tego artykułu wywłaszczenie winno być ujmowane jako „wszelkie przypadki przymusowej ingerencji państwa $\mathrm{w}$ uprawnienie przysługujące innym podmiotom prawnym wobec określonej rze-

2 Konstytucja Rzeczypospolitej Polskiej z dnia 2 kwietnia 1997 r. (Dz.U. z 1997 r., nr 78, poz. 483 ze zm.).

3 W. Skrzydło, Konstytucja Rzeczypospolitej Polskiej. Komentarz, Warszawa 2007, s. 26, za: L. Klat-Wertelecka, [w:] E. Klat-Górska, L. Klat-Wertelecka, Ustawa o gospodarce nieruchomościami. Komentarz, Warszawa 2015, LexOmega nr 9662, http://lex.adm.uj.edu.pl/lex/index. rpc?\&fromHistory=false [dostęp: 22.08.2016]. 
czy, w szczególności nieruchomości”" , nie zaś - jak twierdzi część przedstawicieli doktryny - jako „każde przymusowe odjęcie własności na cel publiczny i na rzecz podmiotu publicznego" ${ }^{5}$. Nie widać bowiem przesłanek, aby wywłaszczenie $\mathrm{z}$ art. 21 ust. 2 Konstytucji RP ograniczać jedynie do prawa własności. Byłoby to niezrozumiałe w perspektywie regulacji art. 64 ust. 3 Konstytucji RP, który stanowi, że wywłaszczenie prawa własności musi być dokonane na podstawie ustawy. Gdyby ustrojodawcy chodziło o ograniczenie rozumienia wywłaszczenia z art. 21 ust. 2 tylko do prawa własności, to już w tym przepisie by stwierdził, że uregulowanie takiego aktu należy do materii ustawowej. W związku z tym należy stwierdzić, że w świetle przepisów Konstytucji RP wywłaszczenie w ogólności nie jest obwarowane wymogiem regulacji ustawowej, zaś wywłaszczenie własności na podstawie art. 64 ust. 3 wymaga formy ustawy.

Konstytucja RP nie ogranicza wywłaszczenia tylko do nieruchomości. Literalne brzmienie art. 112 u.g.n. wskazuje jednak, że regulacja ta dotyczy tylko nieruchomości. W związku z tym, mimo że Konstytucja RP nie wyklucza możliwości wywłaszczenia ruchomości, trzeba stwierdzić, że ustawa o gospodarce nieruchomościami nie daje $\mathrm{w}$ żadnym razie ku temu podstaw.

$\mathrm{Z}$ przepisu art. 112 u.g.n. wynika szereg elementów, jakimi cechuje się wywłaszczenie, na które wskazywano już w literaturze ${ }^{6}$. Po pierwsze, wywłaszczyć można, jak już wyżej wskazano, tylko nieruchomość, o ile jest położona na obszarze przeznaczonym w planie miejscowym na cele publiczne lub co do której wydano decyzję o ustaleniu lokalizacji inwestycji celu publicznego.

Po drugie, instytucja polega na pozbawieniu lub ograniczeniu prawa rzeczowego. Chodzi tutaj zarówno o prawo własności, prawo użytkowania wieczystego, jak i ograniczone prawa rzeczowe. W żadnym razie nie jest dopuszczalne wywłaszczenie prawa obligacyjnego, takiego jak najem czy dzierżawa. Ponadto ograniczenie prawa rzeczowego może polegać albo na stricte ograniczeniu możliwości korzystania z niego, albo na ustanowieniu nowego ograniczonego prawa na nieruchomości. Słusznie wskazuje się, że możliwości takiego ograniczenia nie można sprowadzać tylko do ustanowienia takiego prawa ${ }^{7}$.

Po trzecie, wywłaszczenie musi być dokonane w drodze decyzji. Decyzja ta, oprócz określonych w art. $107 \S 1$ Kodeksu postępowania administracyjne-

4 G. Bieniek, S. Rudnicki, M. Gdesz, Nieruchomości. Problematyka prawna, Warszawa 2013, LexOmega nr 203644, http://lex.adm.uj.edu.pl/lex/index.rpc?\&fromHistory=false [dostęp: 22.08.2016].

5 B. Wierzbowski, Gospodarka nieruchomościami. Podstawy prawne, Warszawa 2014, LexOmega nr 213849, http://lex.adm.uj.edu.pl/lex/index.rpc?\&fromHistory=false [dostęp: 22.08.2016].

6 W. Ramus, Wywłaszczenie nieruchomości, Warszawa 1988, s. 28, za: L. Klat-Wertelecka, op. cit., art. 112.

7 G. Bieniek, S. Rudnicki, M. Gdesz, op. cit. 
go $^{8}$ podstawowych wymagań, musi spełniać szczególne wymagania określone w art. 119 u.g.n. - między innymi wskazywać cel publiczny, na który dokonuje się wywłaszczenia. Pojęcie celu publicznego zdefiniowano ustawowo w sposób wyczerpujący w art. 6 u.g.n. (cele są wymienione enumeratywnie) $)^{9}$. Musi on być ściśle powiązany z prawami i obowiązkami władzy publicznej, nie wyłączając publicznej administracji świadczącej ${ }^{10}$. To, że wywłaszczenie $z$ istoty swej jest aktem indywidualnym, skierowanym do konkretnego podmiotu, odróżnia je wyraźnie od instytucji nacjonalizacji, która jest przeprowadzana za pomocą przepisów rangi ustawowej i obejmuje szerszą grupę podmiotów. Z aktami prawnymi tego typu mieliśmy do czynienia w okresie kształtowania się powojennego ustroju Polski w latach 40. i 50. XX w. ${ }^{11}$

Po czwarte, ust. 3 art. 112 u.g.n. statuuje dwie kolejne przesłanki wywłaszczenia, a mianowicie:

- cele publiczne nie mogą być zrealizowane w inny sposób niż przez pozbawienie albo ograniczenie praw do nieruchomości. Wynika to z faktu, że wywłaszczenie (jak i w ogóle użycie władztwa administracyjnego) powinno być przez organ stosowane zawsze jako ultima ratio. Należy przyjąć przy tym, że przesłanka ta jest spełniona, gdy inne osiągnięcie celu jest wykluczone $^{12}$, więc jeżeli istnieje choćby cień szansy uniknięcia wywłaszczenia, to organ powinien $\mathrm{z}$ tej możliwości skorzystać,

- prawa, które mają być przedmiotem wywłaszczenia, nie mogą być nabyte w drodze umowy. Chodzi tutaj nie tylko o brak zgody potencjalnie wywłaszczanego na zbycie prawa przez umowę. Dotyczy to także nieruchomości o tzw. nieuregulowanym statusie prawnym, tj. gdy uprawnieni są nieznani lub nie można ich odnaleźć.

\section{INSTYTUCJA ZWROTU WYWŁASZCZONEJ NIERUCHOMOŚCI}

Instytucję zwrotu wywłaszczonej nieruchomości statuuje art. 136 u.g.n. Ust. 1 stanowi przede wszystkim zakaz użycia nieruchomości na inne cele niż określone w decyzji o wywłaszczeniu. Jest to emanacja zasady związania organu decyzją

${ }^{8}$ Ustawa z dnia 14 czerwca 1960 r. - Kodeks postępowania administracyjnego (t.j. Dz.U. z 2016 r., nr 23), dalej jako: k.p.a.

${ }^{9}$ M. Szalewska, Wywłaszczenie nieruchomości, Toruń 2005, s. 99, za: L. Klat-Wertelecka, op. cit., art. 112.

${ }^{10}$ B. Wierzbowski, op. cit.

${ }^{11}$ G. Bieniek, S. Rudnicki, M. Gdesz, op. cit.

${ }^{12}$ E. Bończak-Kucharczyk, Ustawa o gospodarce nieruchomościami. Komentarz, Warszawa 2014, LexOmega nr 8979, http://lex.adm.uj.edu.p1/lex/index.rpc?\&fromHistory=false [dostęp: 22.08.2016]. 
z art. 110 k.p.a. Następnie ust. 2 i 3 stanowią dwie oddzielne podstawy do zwrotu wywłaszczonej nieruchomości. Ust. 2 mówi o zmianie celu, na jaki nieruchomość ma zostać przeznaczona, zaś ust. 3 wraz z art. 137 wprowadzają pojęcie zbędności na cele wywłaszczenia. Ust. 5 art. 136, korespondujący bezpośrednio z ust. 2 i 3 wyżej wymienionego artykułu, wprowadza termin 3 miesięcy od dnia otrzymania zawiadomienia o możliwości zwrotu, po bezskutecznym upływie którego wygasa możliwość zwrotu wywłaszczonej nieruchomości. Jak podnosi Trybunał Konstytucyjny w orzeczeniu SK 22/01 ${ }^{13}$, zwrot nieruchomości wywłaszczonej w powyższych przypadkach jest oczywistą konsekwencją przesłanek wywłaszczenia z art. 21 ust. 2 Konstytucji RP. W literaturze podnosi się, że możliwy jest zwrot jedynie prawa pozbawionego, a nie ograniczonego ${ }^{14}$. Decyzja w przedmiocie zwrotu ma funkcję restytucyjną, czyli przywracającą określony stan prawny. Ma ona charakter konstytutywny i według przeważającej części autorów wywołuje bezpośrednie skutki cywilnoprawne ${ }^{15}$. Dyskusyjnym aspektem jest natomiast zakres zastosowania art. 136 u.g.n. W doktrynie sporne jest, czy można zwrócić tylko nieruchomość wywłaszczoną na podstawie obowiązującej ustawy o gospodarce nieruchomościami, czy również pod rządami innych aktów prawnych. Należy przyjąć, że sformułowanie użyte w ustawie („zwrot wywłaszczonej nieruchomości”) odnosi się do wszystkich aktów wywłaszczenia, bez względu na moment dokonania tego aktu. Ustawa bowiem nie rozróżnia, czy chodzi o wywłaszczenie na podstawie niniejszej ustawy czy nie, więc pojęcie „wywłaszczenie” trzeba interpretować abstrakcyjnie jako instytucję prawa publicznego, a nie samej ustawy o gospodarce nieruchomościami ${ }^{16}$.

Z zupełnie innym przypadkiem mamy do czynienia, analizując przepis art. 216 u.g.n. Stanowi on, że przepisy o zwrocie wywłaszczonej nieruchomości stosuje się odpowiednio do nieruchomości przejętych lub nabytych na rzecz Skarbu Państwa. Dalej ustawa wymienia podstawy, do których stosuje się przepisy tego rozdziału. Użycie przez ustawodawcę określenia „przejęcie i nabycie nieruchomości na rzecz Skarbu Państwa" należy uznać za pojęcie szersze od wywłaszczenia. Chodzi tutaj o przypadki inne niż wywłaszczenie, do których na podstawie art. 216 stosuje się przepisy u.g.n. dotyczące zwrotu wywłaszczonej nieruchomości ${ }^{17}$.

${ }^{13}$ Wyrok TK z dnia 24 października 2001 r., SK 22/01 (Dz.U. z 2001 r., nr 129, poz. 1447).

14 E. Bończak-Kucharczyk, op. cit., art. 136.

15 Por. np. M. Wolanin, Ustawa o gospodarce nieruchomościami. Komentarz, Warszawa 2011, s. 1087; T. Woś, Wywłaszczanie i zwrot wywłaszczonych nieruchomości, Warszawa 2011, s. 547; E. Bończak-Kucharczyk, op. cit., art. 136.

${ }^{16}$ G. Bieniek, [w:] Ustawa o gospodarce nieruchomościami. Komentarz, red. G. Bieniek, Warszawa 2008, s. 692; T. Woś, op. cit., s. 398; P. Wojciechowski, [w:] Ustawa o gospodarce nieruchomościami. Komentarz, red. P. Czechowski, Warszawa 2015, LexOmega nr 10144, http://lex.adm. uj.edu.pl/lex/index.rpc?\&fromHistory=false [dostęp: 22.08.2016].

17 Por. wyrok TK z dnia 9 grudnia 2008 r., SK 43/07 (Dz.U. z 2008 r., nr 223, poz. 1476). 
Wywłaszczający nie może używać nieruchomości w celu innym niż wskazany w decyzji wywłaszczeniowej. Zakaz ten obowiązuje do momentu wyraźnej lub milczącej (przez niezłożenie w ciągu 3 miesiący wniosku o zwrot) zgody wywłaszczonego lub jego spadkobiercy. Nasuwa się pytanie, co należy rozumieć pod pojęciem „użycie nieruchomości”. Według Sądu Najwyższego ${ }^{18}$ jest to nie tylko gospodarcze przeznaczenie nieruchomości i jej fizyczne wykorzystanie, ale także rozporządzanie nieruchomością w drodze czynności prawnej.

W kwestii samego wniosku o zwrot narosło sporo wątpliwości. Przede wszystkim trzeba stwierdzić, że termin trzymiesięczny nie podlega przywróceniu. Po jego upływie uprawnienie do zwrotu wygasa. Jeżeli do złożenia wniosku uprawnionych jest kilka osób, to mamy do czynienia z jedną sprawą administracyjną. Aby dokonać skutecznego złożenia tego wniosku, wszyscy uprawnieni muszą to zrobić, ponieważ przysługuje im w tym przypadku legitymacja łączna. Wynika z tego fakt, że termin 3 miesięcy płynie dopiero po zawiadomieniu ostatniego uprawnionego o możliwości zwrotu ${ }^{19}$. Część przedstawicieli doktryny przyjmuje tutaj niezależność biegu terminów, lecz należy zauważyć, że gdyby termin bezskutecznie minął co do pierwszego z uprawnionych, to wtedy złożenie wniosku przez resztę uprawnionych $\mathrm{w}$ terminie nie mogłoby prowadzić do zwrotu wywłaszczonej nieruchomości ${ }^{20}$.

W przypadku powzięcia zamiaru zmiany celu wykorzystania nieruchomości ustawa nakłada na wywłaszczającego obowiązek poinformowania o tym wywłaszczonego. Nie musi on jednak tego robić, jeśli nie wykona celu z decyzji o wywłaszczeniu, ale też nie zmieni tego celu na inny ${ }^{21}$. Gdy sam akt zawiadomienia konkretnej osoby jest niemożliwy (np. jest ona nieznana), możliwe jest obwieszczenie tego faktu na podstawie art. 49 k.p.a. Warto podkreślić, że organ ma obowiązek poszukiwania z urzędu poprzedniego właściciela lub jego spadkobiercy. Nie musi przy tym poszukiwać uprawnionych, którzy nie złożyli wniosku, a jedynie informować strony w rozumieniu art. 28 k.p.a. o możliwości złożenia wniosku o zwrot ${ }^{22}$.

Problem pojawia się, gdy organ złamie zakaz użycia nieruchomości i wykorzysta ją na cel inny niż określony w decyzji o wywłaszczeniu, i to bez zawiadomienia. Sąd Najwyższy ${ }^{23}$ uważa, że podmiot wywłaszczający nie może dokonywać skutecznych czynności prawnych przy korzystaniu z nieruchomości w innym celu (np. zbycia jej bez wykonania celu wywłaszczenia), a każda czynność naruszająca

\footnotetext{
${ }^{18}$ Wyrok SN z dnia 8 sierpnia 2001 r., I CKN 1102/98, LEX nr 110623.

19 E. Mzyk, [w:] Ustawa o gospodarce nieruchomościami ..., s. 476.

${ }^{20}$ P. Wojciechowski, op. cit., art. 136.

21 T. Woś, op. cit., s. 364.

22 Wyrok WSA w Krakowie z dnia 23 stycznia 2009 r., II SA/Kr 1119/08, LEX nr 531021.

${ }^{23}$ Wyrok SN z dnia 30 kwietnia 1987 r., III CZP 19/87, OSNC 1988/7-8/96; wyrok SN z dnia 21 czerwca 2007 r., IV CSK 81/07, Biul. SN 2007/12/11.
} 
zakaz jest nieważna na podstawie art. $58 \S 1$ k.c. ${ }^{24}$ Zajmując takie stanowisko, należałoby uznać, że zakaz z art. 136 ust. 1 jest swoistym ograniczeniem własności podmiotu wywłaszczającego. Nie dotyczy to sytuacji, gdy wcześniej wykonano cel określony w wywłaszczeniu, a następnie wykorzystano nieruchomość na inne cele $^{25}$. W innych orzeczeniach Sąd Najwyższy stwierdził, że złamanie tego zakazu nie może powodować nieważności czynności prawnej i prowadzi tylko do odpowiedzialności odszkodowawczej ${ }^{26}$. Wreszcie według części autorów ${ }^{27}$ (między innymi T. Wosia czy J. Szachułowicza) istnieje tutaj możliwość zastosowania art. 59 k.c., aby uznać czynność prawną za nieskuteczną wobec pokrzywdzonego przez nią uprawnionego do zwrotu nieruchomości. Analizując wyżej przedstawione zapatrywania literatury i orzecznictwa, godzi się stwierdzić, że właściwe wydaje się uznanie za nieważne czynności prawnych dokonanych przez wywłaszczającego wraz ze złamaniem zakazu z art. 136 ust. 1 u.g.n. Art. 58 § 1 k.c. stanowi wprost, że czynność prawna sprzeczna z ustawą jest nieważna. Art. 136 ust. 1 u.g.n. wyraźnie wskazuje zaś, że nieruchomość nie może być użyta na inny cel niż wskazany w decyzji o wywłaszczeniu. Jakakolwiek czynność prawna (w rozumieniu prawa cywilnego), która prowadziłaby do użycia tej nieruchomości na cele inne niż określone w wywłaszczeniu, prowadziłaby zatem jednocześnie do wywołania stanu sprzecznego z art. 136 ust. 1 u.g.n., tj. do wypełnienia hipotezy art. $58 \S 1$ k.c. Nie ma wobec tego podstaw, aby taka czynność wywoływała skutki prawne.

Kolejną kwestią nasuwającą pytania jest to, na jaki cel organ może przeznaczyć nieruchomość, gdy zakaz z art. 136 ust. 1 u.g.n. już go nie obowiązuje. Należy stwierdzić, że musi to być cel publiczny, a nie jakikolwiek cel. Co prawda, art. 136 u.g.n. nie precyzuje tej kwestii, ale robi to Konstytucja RP w art. 21 ust. 2, wskazując na cel publiczny. Poprawna jest też konstatacja, że cel ten musi wynikać z zawiadomienia. Poglądy nauki nie są jednak w pełni jednolite, jeżeli chodzi o to twierdzenie ${ }^{28}$.

Część przedstawicieli doktryny twierdzi, że w przypadku wielości uprawnionych do zwrotu, gdy jeden z nich wystąpi z wnioskiem o zwrot, to organ nie może użyć nieruchomości na inny cel ${ }^{29}$. Przyjmuje się, że jeden wniosek nie jest w tej sytuacji wystarczający do uzyskania zwrotu (patrz wyżej).

${ }^{24}$ Ustawa z dnia 23 kwietnia 1964 r. - Kodeks cywilny (t.j. Dz.U. z 2016 r., nr 380), dalej jako: k.c.

${ }_{25}$ Wyrok TK z dnia 13 grudnia 2012 r., P 12/11 (Dz.U. z 2012 r., poz. 1472).

${ }^{26}$ Wyrok SN z dnia 30 kwietnia 1987 r., III CZP 19/87, OSNC 1988/7-8/96; wyrok SN z dnia 21 czerwca 2007 r., IV CSK 81/07, Biul. SN 2007/12/11; P. Wojciechowski, op. cit., art. 136.

27 J. Szachułowicz, Gospodarka nieruchomościami, Warszawa 2005, s. 203; T. Woś, op. cit., s. 36.

${ }^{28}$ Stanowisko pozytywne w tym względzie prezentuje P. Wojciechowski (op. cit., art. 136), zaś pogląd odmienny ma J. Szachułowicz (op. cit., s. 201), uważając, że brak złożenia wniosku w terminie 3 miesięcy powoduje możliwość wykorzystania nieruchomości na jakikolwiek cel.

29 T. Woś, op. cit., s. 362; P. Wojciechowski, op. cit., art. 136. 
Zbędność nieruchomości na cel wskazany w decyzji wywłaszczeniowej, określona w art. 137 u.g.n., jest również podstawą do domagania się zwrotu wywłaszczonej nieruchomości. Przepis ten stanowi o przesłankach uznania nieruchomości za zbędną na cele wywłaszczenia. Jest to odpowiednio brak rozpoczęcia prac związanych z realizacją celu mimo upływu 7 lat od dnia, w którym decyzja stała się ostateczna lub fakt, że celu nie zrealizowano mimo upływu 10 lat od tego dnia. Właściwie bezkrytycznie przyjmuje się, że jest to zamknięty katalog przesłanek uznania nieruchomości za zbędną na cele wywłaszczenia. Należy jednak zwrócić uwagę, że art. 137 ust. 1 u.g.n. wskazuje literalnie na fikcję prawną. Chodzi tutaj o zwrot „nieruchomość uznaje się za zbędną”. Można z tego wyprowadzić wniosek, że pojęcie nieruchomości zbędnej na cele wywłaszczenia jest nieostre i powinno być za każdym razem oceniane przez organ administracji publicznej, a art. 137 u.g.n. nakazuje organowi uznać za zbędną nieruchomość w przypadkach w tym przepisie określonych, bez względu na to, czy rzeczywiście stała się ona zbędna na cele wywłaszczenia.

Celowe jest tutaj posłużenie się przykładem. Organ wywłaszcza nieruchomość celem budowy szpitala, ale nie otrzymuje dofinansowania z funduszy unijnych, na które liczył, dokonując wywłaszczenia. W związku z tym przez 8 lat nie zaczął budowy ze względu na brak środków. $Z$ logicznego punktu widzenia nie można stwierdzić, że działka jest zbędna na cele budowy szpitala, nadal bowiem planuje się w przyszłości go wybudować. Przyjąć więc należy, że art. 137 u.g.n. ma tylko za zadanie przez fikcję prawną przerwać stan niepewności prawnej. Pełni on funkcję gwarancyjną i jest emanacją zasady wywłaszczenia jako środka ultima ratio. Trzeba podkreślić, że nieruchomość można uznać za zbędną na cele wywłaszczenia także w innych przypadkach niż wskazane w art. 137 u.g.n. W świetle art. 136 ust. 3 podstawą zwrotu jest jednak tylko zbędność określona w art. 137 u.g.n. Powyższy przykład może też działać w „odwrotnym” stanie faktycznym, gdyż nieruchomość może stać się zbędna również przed upływem przewidzianych w przepisie terminów. Nielogiczne byłoby wtedy oczekiwanie na upłynięcie tego terminu, gdy np. działka nie jest w ogóle użytkowana. De lege ferenda należy stwierdzić, że powinno się rozszerzyć zastosowanie art. 136 ust. 3 u.g.n. o inne przypadki zbędności nieruchomości na cele wywłaszczenia. De lege lata natomiast przesłanki zwrotu są ograniczone jedynie do zbędności w rozumieniu art. 137 u.g.n.

W związku z literalnym brzmieniem art. 137 u.g.n. kluczowe jest ustalenie, co znaczy stwierdzenie: „rozpocząć prace związane z realizacją celu”. Ma to bowiem znaczący wpływ na to, jaką nieruchomość możemy uznać w świetle ustawy za zbędną na cele wywłaszczenia. Słusznie podnosi się ${ }^{30}$, że nie wystarczą tutaj czynności formalne. Konieczne są działania faktyczne zmierzające do wykonania 
celu wywłaszczenia. Za takie prace nie można uznać prac projektowych, przygotowawczych czy prowadzonych poza nieruchomością ${ }^{31}$.

Nie do końca jasne było znaczenie określenia: „Zwrot nieruchomości w części”. Wojewódzki Sąd Administracyjny w Krakowie trafnie podniósł, że co prawda nie ma w ustawie zakazu zwrócenia ułamkowej części nieruchomości, ale w przepisie art. 137 ust. 2 u.g.n. mówi się o nieruchomości, a nie o udziale we własności nieruchomości. Chodzi tutaj zatem o część fizyczną nieruchomości ${ }^{32}$.

Mimo literalnego brzmienia art. 136 u.g.n., który mówi tylko o poprzednim właścicielu lub jego spadkobiercy, należy przyjąć, że do żądania zwrotu są też uprawnione inne podmioty, które mogą być pozbawione prawa przez wywłaszczenie (np. użytkownik wieczysty). Zwrotu może żądać osoba fizyczna, prawna lub jednostka organizacyjna nieposiadająca osobowości prawnej. Ponadto, gdy wywłaszczenia dokonano po upływie terminu zasiedzenia, podmiotem uprawnionym do zwrotu jest właściciel, który nabył nieruchomość przez zasiedzenie. Nie jest przy tym istotne, czy zapadło w tej sprawie orzeczenie o stwierdzeniu zasiedzenia (ma ono charakter deklaratoryjny) $)^{33}$. Jako że prawo do zwrotu nieruchomości wywłaszczonej należy pojmować jako publiczne prawo podmiotowe, jest ono niezbywalne ${ }^{34}$. T. Woś podkreśla, że „za spadkobierców nie można [...] uznać następców prawnych poprzedniego właściciela będącego osobą prawną"35.

Dyskusyjne jest to, czy uprawnienie do zwrotu przysługuje, gdy nieruchomość została co prawda wykorzystana na cele wywłaszczenia, ale dopiero po upływie terminów określonych w art. 137 u.g.n. Dominujący pogląd to ten, którego zwolennicy przyjmują, że w takiej sytuacji można zwrócić nieruchomość (po 7 latach, 10 latach $)^{36}$. Jego przeciwnicy zaś uważają, że takiego rozumowania nie da się pogodzić z zasadą stabilności porządku prawnego. Warto zwrócić uwagę np. na sytuację, gdy na terenie wywłaszczonej nieruchomości wybudowano drogę publiczną lub kopalnię. W tym przypadku przyznanie uprawnienia do zwrotu byłoby nielogiczne i niecelowe. Pogląd ten został wyrażony między innymi przez Wojewódzki Sąd Administracyjny w Krakowie, który stwierdził, że jeżeli „,el wywłaszczenia został zrealizowany, to zwrot nie jest możliwy bez względu na to, kiedy realizacja nastąpi-

${ }^{31}$ E. Bończak-Kucharczyk, op. cit., art. 137.

32 Wyrok WSA w Krakowie z dnia 23 stycznia 2009 r., II SA/Kr 1119/08, LEX nr 531021.

33 Wyrok NSA z dnia 10 maja 1999 r., IV SA 811/97, ONSA 2000/2/80.

34 Postanowienie SN z dnia 27 lutego 2002 r., III CKN 520/00, OSNC 2003/2/26; wyrok NSA z dnia 27 kwietnia 2007 r., I OSK 844/06, LEX nr 329149.

35 T. Woś, op. cit., s. 547.

36 Wyrok NSA z dnia 4 września 2003 r., II SA/Gd 1552/00, LEX nr 298527; wyrok NSA z dnia 1 października 2010 r., I OSK 1612/09, LEX nr 745102; wyrok NSA z dnia 25 marca 2011 r., I OSK 777/10, LEX nr 1079826; wyrok NSA w Warszawie z dnia 2 czerwca 2011 r., I OSK 1125/10, LEX nr 1082567. 
ła" ${ }^{37}$. Mając na uwadze cel instytucji zbędności na cele wywłaszczenia, nie można się zgodzić, że w jakimkolwiek przypadku po zrealizowaniu celu wywłaszczenia zwrot jest możliwy, a zatem należy poprzeć stanowisko Wojewódzkiego Sądu Administracyjnego w Krakowie. Art. 137 u.g.n., jak już wyżej wskazano, ma na celu zakończenie stanu niepewności prawnej, która w przypadku zrealizowania celu wywłaszczenia nie istnieje.

Zwrot jest możliwy tylko wtedy, gdy wywłaszczone prawo do nieruchomości nadal przysługuje podmiotowi wywłaszczającemu (nie jest np. dopuszczalny zwrot, gdy wywłaszczenia dokonał Skarb Państwa, a następnie nieruchomość została objęta komunalizacją na rzecz jednostki samorządu terytorialnego) ${ }^{38}$.

Problematyczna jest nieporuszana w literaturze kwestia odszkodowania za wywłaszczenie i obowiązek jego zwrotu. Przepis art. 136 ust. 3 in fine u.g.n. przewiduje bowiem zwrot odszkodowania przy zwrocie nieruchomości, gdy ta stała się zbędna na cele wywłaszczenia. W domyśle można przyjąć, że chodzi o całość odszkodowania. Trzeba wziąć jednak pod uwagę fakt, że wywłaszczający posiadał przez okres od wywłaszczenia do zwrotu władztwo nad rzeczą, a uprawniony do zwrotu nie, w związku z tym należy mu się odszkodowanie za ten okres. Wydaje się, że nie można przyjąć tutaj miarkowania odszkodowania ze względu na charakter prawa publicznego i użycie władztwa w realiach wywłaszczenia. Zarazem nic nie stoi na przeszkodzie, aby uprawniony domagał się wynagrodzenia od państwa na podstawie k.c. Podkreślenia wymaga przy tym fakt, że u.g.n. nie może być podstawą do tego typu roszczeń.

Nieruchomość jest zwracana na mocy samej decyzji administracyjnej o zwrocie. Nie można zgodzić się z tym, że nieruchomość zamienna również zostaje zwrócona na tej podstawie. W momencie wywłaszczenia staje się ona bowiem własnością wywłaszczanego, więc w celu odebrania mu własności konieczna jest jego czynność prawna, wymagająca określonej formy na podstawie k.c. Inna wykładnia prowadziłaby do sprzeczności z art. 21 ust. 2 Konstytucji RP. Do pozbawienia własności nieruchomości na mocy decyzji potrzebna byłaby kolejna decyzja o wywłaszczeniu nieruchomości, tym razem zamiennej, do której, co oczywiste, nie ma w tym przypadku przesłanek.

\section{PODSUMOWANIE}

Tytułem podsumowania należy stwierdzić, że przepisy dotyczące wywłaszczenia oraz zwrotu wywłaszczonej nieruchomości nie zawsze są sformułowane w sposób w pełni jasny i zrozumiały. De lege ferenda można wskazać przede wszystkim

\footnotetext{
${ }^{37}$ Wyrok WSA w Krakowie z dnia 20 marca 2015 r., II SA/Kr 155/15, LEX nr 1787534.

${ }^{38}$ M. Wolanin, op. cit., s. 1060.
} 
wspomniane rozszerzenie zastosowania art. 136 u.g.n. również o inne przypadki zbędności nieruchomości na cele wywłaszczenia. Przysporzyłoby to regulacji elastyczności i poprawiłoby skuteczność wypełniania jej funkcji gwarancyjnej, tak istotnej w demokratycznym państwie prawnym, w szczególności ze względu na stopień ingerencji wywłaszczenia w prawa i wolności jednostki.

Przepisy prawne dotyczące analizowanej materii należy w ogólności uznać za wystarczające do właściwej ochrony jednostki. Wszelkie problemy interpretacyjne, jakie pojawiają się na gruncie ustawy, są możliwe do wyjaśnienia przez doktrynę i orzecznictwo, stosujące ogólne reguły racjonalnej wykładni prawa. Nie wolno przy tym, co trzeba podkreślić, zapominać o odmiennym charakterze przepisów prawa prywatnego i prawa publicznego. Jest to szczególnie ważne na gruncie choćby ustawy o gospodarce nieruchomościami, która łączy regulację publicznoprawną i prywatnoprawną $\mathrm{w}$ ramach jednego aktu prawnego.

Zagadnienie zwrotu wywłaszczonych nieruchomości było i jest żywe w doktrynie prawa administracyjnego głównie ze względu na serię bezprawnych wywłaszczeń podczas kształtowania się powojennej Polski. Ponadto instytucja ta jest związana ze znacznym wkroczeniem w sferę praw i wolności jednostki nie tylko materialnie, ale też moralnie i emocjonalnie (np. przez eksmisję z wieloletniego miejsca zamieszkania). W związku z tym, formułując ogólne reguły postępowania, trzeba stwierdzić, że organy wywłaszczeniowe powinny traktować te stany faktyczne z dużą troską i uwagą, stosując prawo wywłaszczeniowe ze szczególnym uwzględnieniem delikatności regulowanej przez nie materii.

\section{BIBLIOGRAFIA}

Bieniek G., [w:] Ustawa o gospodarce nieruchomościami. Komentarz, red. G. Bieniek, Warszawa 2008.

Bieniek G., Rudnicki S., Gdesz M., Nieruchomości. Problematyka prawna, Warszawa 2013, LexOmega nr 203644, http://lex.adm.uj.edu.pl/lex/index.rpc?\&fromHistory=false [dostęp: 22.08.2016].

Bończak-Kucharczyk E., Ustawa o gospodarce nieruchomościami. Komentarz, Warszawa 2014, LexOmega nr 8979, http://lex.adm.uj.edu.pl/lex/index.rpc?\&fromHistory=false [dostęp: 22.08.2016].

Klat-Wertelecka L., [w:] E. Klat-Górska, L. Klat-Wertelecka, Ustawa o gospodarce nieruchomościami. Komentarz, Warszawa 2015, LexOmega nr 9662, http://lex.adm.uj.edu.pl/lex/index. rpc?\&fromHistory=false [dostęp: 22.08.2016].

Konstytucja Rzeczypospolitej Polskiej z dnia 2 kwietnia 1997 r. (Dz.U. z 1997 r., nr 78, poz. 483 ze zm.).

Mzyk E., [w:] Ustawa o gospodarce nieruchomościami. Komentarz, red. G. Bieniek, Warszawa 2008.

Postanowienie SN z dnia 27 lutego 2002 r., III CKN 520/00, OSNC 2003/2/26.

Ramus W., Wywłaszczenie nieruchomości, Warszawa 1988.

Skrzydło W., Konstytucja Rzeczypospolitej Polskiej. Komentarz, Warszawa 2007.

Szachułowicz J., Gospodarka nieruchomościami, Warszawa 2005.

Szalewska M., Wywłaszczenie nieruchomości, Torun 2005.

Ustawa z dnia 14 czerwca 1960 r. - Kodeks postępowania administracyjnego (t.j. Dz.U. z 2016 r., nr 23). 
Ustawa z dnia 23 kwietnia 1964 r. - Kodeks cywilny (t.j. Dz.U. z 2016 r., nr 380).

Ustawa z dnia 21 sierpnia 1997 r. o gospodarce nieruchomościami (t.j. Dz.U. z 2015 r., nr 1774).

Wierzbowski B., Gospodarka nieruchomościami. Podstawy prawne, Warszawa 2014, LexOmega nr 213849, http://lex.adm.uj.edu.pl/lex/index.rpc?\&fromHistory=false [dostęp: 22.08.2016].

Wojciechowski P., [w:] Ustawa o gospodarce nieruchomościami. Komentarz, red. P. Czechowski, Warszawa 2015, LexOmega nr 10144, http://lex.adm.uj.edu.pl/lex/index.rpc?\&fromHistory=false [dostęp: 22.08.2016].

Wolanin M., Ustawa o gospodarce nieruchomościami. Komentarz, Warszawa 2011.

Woś T., Wywłaszczanie i zwrot wywłaszczonych nieruchomości, Warszawa 2011.

Wyrok NSA w Warszawie z dnia 2 czerwca 2011 r., I OSK 1125/10, LEX nr 1082567.

Wyrok NSA z dnia 10 maja 1999 r., IV SA 811/97, ONSA 2000/2/80.

Wyrok NSA z dnia 4 września 2003 r., II SA/Gd 1552/00, LEX nr 298527.

Wyrok NSA z dnia 27 kwietnia 2007 r., I OSK 844/06, LEX nr 329149.

Wyrok NSA z dnia 1 października 2010 r., I OSK 1612/09, LEX nr 745102.

Wyrok NSA z dnia 25 marca 2011 r., I OSK 777/10, LEX nr 1079826.

Wyrok SN z dnia 30 kwietnia 1987 r., III CZP 19/87, OSNC 1988/7-8/96.

Wyrok SN z dnia 8 sierpnia 2001 r., I CKN 1102/98, LEX nr 110623.

Wyrok SN z dnia 21 czerwca 2007 r., IV CSK 81/07, Biul. SN 2007/12/11.

Wyrok TK z dnia 24 października 2001 r., SK 22/01 (Dz.U. z 2001 r., nr 129, poz. 1447).

Wyrok TK z dnia 9 grudnia 2008 r., SK 43/07 (Dz.U. z 2008 r., nr 223, poz. 1476).

Wyrok TK z dnia 13 grudnia 2012 r., P 12/11 (Dz.U. z 2012 r., poz. 1472).

Wyrok WSA w Krakowie z dnia 23 stycznia 2009 r., II SA/Kr 1119/08, LEX nr 531021.

Wyrok WSA w Krakowie z dnia 20 marca 2015 r., II SA/Kr 155/15, LEX nr 1787534.

\section{SUMMARY}

The article considers the institution of return of expropriated estate. The first part of the text is devoted to the expropriation itself as an imperious construction of public law in the light of elementary constitutional rules of Polish law order. Expropriation has been described by pointing and considering its particular premises, both positive and negative. The main part is focused on the statutory institution of return of expropriated estate, stated by Article 136 et seq of Real Estate Management Act of August 21, 1997, around which, according to the series of expropriations performed at the time of Polish postwar political system creation, a lot of legal doubts have arisen. The article deliberates each of significant premises of return, for instance the acknowledgement of estate as redundant for expropriation purposes (which seems not to be discussed in legal doctrine), deliberating the main points of doctrine and judicature. The text comes up with a few important de lege ferenda proposals in order to shape abovementioned construction distinctly.

Keywords: return; expropriation; estate; redundancy; real estate management 